\title{
Effect of Trichloroacetic Acid on the Bond Strength of Calcium Silicate-Based Cements: A Modified Push-Out Test
}

\author{
Trikloroasetik Asidin Kalsiyum Silikat Esaslı Simanların Bağlanma Dayanımı \\ Üzerindeki Etkisi: Modifiye itme Testi
}

(iD Betül Aycan UYSAL ${ }^{1}$, id Ayça SARIALIOĞLU GÜNGÖR2

1Bezmialem Vakıf University Faculty of Dentistry, Department of Endodontics, İstanbul, Turkey

${ }^{2}$ Bezmialem Vakıf University Faculty of Dentistry, Department of Restorative Dentistry, İstanbul, Turkey

\section{ABSTRACT}

Objective: This study aimed to investigate the effect of trichloroacetic acid (TCA) on the bond strength of calcium silicatebased cements to dentin.

Methods: Ten single-rooted bovine teeth were sectioned longitudinally into slices $2 \mathrm{~mm}$ thick. Six holes were drilled with a $1.2-\mathrm{mm}$ diamond bur in each dentin slice (totally 60 holes). Cotton pellets with TCA were applied to three holes of each slice for $1 \mathrm{~min}$, whereas no acid was applied to the other three. The TCA and nonTCA groups were divided into three subgroups according to the material used: ProRoot mineral trioxide aggregate (MTA; $\mathrm{n}=10$ ), Harvard MTA ( $\mathrm{n}=10)$, and Biodentine $(\mathrm{n}=10)$. After seven days, the dislodgement resistance of the materials was calculated using a universal testing machine. The types of bond failure were examined under a stereomicroscope.

Results: TCA had no statistically significant effect on the bonding strength of the tested materials $(\mathrm{P}>.05)$. The Harvard MTA subgroup had the lowest mean bond strength values $(2.25 \pm 0.79$ $\mathrm{MPa})$, while the Biodentine subgroup had the highest $(10.49 \pm 3.32$ $\mathrm{MPa})$. The most common bond failure types were mixed in the ProRoot MTA subgroup (60\%) and cohesive in the Harvard MTA $(60 \%)$ and Biodentine (70\%) subgroups.

Conclusion: The bond strength of Biodentine is greater than those of ProRoot and Harvard MTA. TCA does not affect the push-out bond strength of MTA or Biodentine.

Keywords: Biodentine; calcium silicate-based cements; mineral trioxide aggregate; push-out bond strength; trichloroacetic acid
ÖZ

Amaç: Bu çalışma, trikloroasetik asidin (TCA) kalsiyum silikat esaslı simanların dentine bağlanma dayanımına etkisini araştırmak amacı ile yapılmıştır.

Yöntemler: Toplam 10 adet tek köklü sığır dişi, 2 mm kalınlığında dilimler halinde uzunlamasına kesitlere ayrıldı. Bu 10 dişten elde edilen her dentin diliminde 1.2 mm'lik elmas frez ile 6 adet delik açıldı (toplam 60 delik). TCA içeren pamuk peletler, her dentin dilimde bulunan 3 deliğe 1 dakika süreyle uygulanırken, diğer 3 deliğe asit uygulanmadı. TCA uygulanan ve TCA uygulanmayan gruplar, kullanılan malzemeye göre tekrar üç alt gruba ayrıldı: ProRoot mineral trioksit agregat (MTA; $\mathrm{n}=10$ ), Harvard MTA ( $\mathrm{n}$ $=10)$ ve Biodentine $(n=10)$. Toplam 7 gün sonra, malzemelerin yerinden çıma direnci evrensel bir test makinesi kullanılarak hesaplandı. Bağlanma başarısızlık türleri bir stereomikroskop altında incelendi.

Bulgular: TCA, test edilen malzemelerin bağlanma dayanımı üzerinde istatistiksel olarak önemli bir etkiye sahip değildi $(P>.05)$. Harvard MTA alt grubu en düşük ortalama bağlanma gücüne sahipken $(2.25 \pm 0.79 \mathrm{MPa})$, Biodentine alt grubu en yüksek değere $(10.49 \pm 3.32 \mathrm{MPa})$ sahipti. En yaygın bağlanma hatası tipleri, ProRoot MTA alt grubunda (\%60) karışık, Harvard MTA (\%60) ve Biodentine (\%70) alt gruplarında ise koheziv bağlanma türünde bulundu.

Sonuç: Biodentine'in bağlanma gücü ProRoot ve Harvard MTA'nınkinden daha fazla bulunmuştur. TCA, MTA veya Biodentine'in itme bağlanma dayanımını etkilememektedir.

Anahtar Sözcükler: Biodentin, itme bağlanma gücü, kalsiyum silikat esaslı siman, mineral trioksit agregat, trikloroasetik asit
Address for Correspondence/Yazışma Adresi: Betül Aycan UYSAL, Bezmialem Vakıf University Faculty of Dentistry, Department of Endodontics, İstanbul, Turkey

E-mail: balim@bezmialem.edu.tr ORCID ID: orcid.org/
Received/Geliş Tarihi: 01.01.2021 Accepted/Kabul Tarihi: 14.02.2021

Cite this article as: Uysal BA, Sarıalioğlu Güngör A. Effect of Trichloroacetic Acid on the Bond Strength of Calcium Silicate-Based Cements: A Modified Push-Out Test. Bezmialem Science. 


\section{Introduction}

Loss of dental hard tissue and root resorption may occur as a result of osteoclastic action (1). Root resorption may be associated with many causes, such as cystic lesions, trauma, impacted teeth, and endocrine disturbances $(2,3)$. External cervical resorption (ECR) is a type of resorption that affects the periodontal ligament, cementum, and dentin most commonly localized at or below the cervical margin (4). When resorption is correctly diagnosed and treated with a biocompatible material with adequate sealing ability, the prognosis can be favorable (5).

Mineral trioxide aggregate (MTA) has many desirable properties, including bactericidal effects, biocompatibility, radiopacity, and good sealing ability (6). However, it also has certain drawbacks, such as a high price, a long setting time, and potential tooth discoloration (7). To overcome these drawbacks, new calcium silicate-based materials have been produced. Biodentine (Septodont, Saint-Maur-des-Fossés, France), a silicate-based cement, exhibits several favorable properties, such as a short setting time, high mechanical strength, and superior handling characteristics (8). It is an effective repair material due to its excellent sealing ability, short setting time, high compressive strength, and biomineralization properties (8-10).

The use of MTA or Biodentine as repair materials is recommended after the elimination of granulomatous tissue in the perforation area (11). In external cervical resorption, topical application of $90 \%$ aqueous trichloroacetic acid (TCA) solution to granulomatous tissue is recommended (12). TCA induces coagulation necrosis, and tissue in the resorption cavity loses its vascularization features. TCA inactivates potentially resorptive cells and penetrates into smaller resorptive areas that may not be cleaned with mechanical instrumentation $(13,14)$.

Several studies have investigated the push-out bond strength of calcium silicate-based cements, such as MTA and Biodentine, to dentin (15-21). However, to our knowledge, no study has examined whether TCA used in ECR has an effect on the pushout bond strength of these materials. Therefore, this study aimed to investigate the effect of TCA on the bond strength of ProRoot MTA (Dentsply Sirona), Harvard MTA (Harvard Dental International, Hoppegarten, Germany), and Biodentine. The null hypotheses were that TCA would not significantly affect push-out bond strength of calcium silicate-based cements and there would be no significant difference in bond strength between the tested materials.

\section{Method}

\section{Sample Preparation}

A total of 10 freshly extracted bovine teeth with single root canals were used to get 60 holes in this study. Animals were slaughtered for feeding purposes, and the teeth were donated to this study. This investigation was not classified as an animal study because our work had no influence on the premortal fate of the animals or the slaughtering process. After the teeth were decoronated, the apical and middle thirds of the roots were removed. Then, sections at a distance of $8 \mathrm{~mm}$ from the coronal thirds were used. The root pieces were embedded in acrylic blocks parallel to the root canal. The root dentin was sectioned longitudinally into slices $2 \mathrm{~mm}$ thick using a cutting machine (Mecatome T180; Presi, Eybens, France) with a disc (Metkon Instruments Inc., Bursa, Turkey) under water cooling. Similar to the study of Orhan et al. (18), six holes were drilled in each dentin slice, three on the right and three on the left side of the root canal to standardize all samples. A size 1.2-mm diameter diamond bur and a highspeed dental handpiece were used (Fig. 1). The holes were drilled midway between the external cementum and the root canal wall. The samples were divided into two groups: TCA $(n=30)$ and non-TCA applied $(n=30)$. Small amounts of $90 \%$ aqueous TCA were absorbed into small cotton pellets and then dampened on gauze. The cotton pellets were applied to three holes of each dentin slice for $1 \mathrm{~min}$ (13), whereas no acid was applied to the other three. The TCA and non-TCA groups were divided into three subgroups according to the material used: ProRoot mineral trioxide aggregate (MTA; $n=10)$, Harvard MTA $(n=10)$, and Biodentine $(n=10)$.

For standardization purposes, ProRoot MTA, Harvard MTA, and Biodentine were incrementally placed in two holes each, one with and one without TCA, in each slice. All materials were prepared according to the manufacturers' instructions. The same procedure was repeated for all 10 samples. Residual material was removed from the dentin surfaces with a scalpel. The dentin slices were subsequently placed in wet gauze and then placed in an incubator at $37^{\circ} \mathrm{C}$ with $100 \%$ humidity for seven days.

\section{Push-Out Test}

A universal testing machine (Instron Universal; Elista, Istanbul, Turkey) was used to calculate the push-out bond strength of the materials. The samples were placed on a metal plate with a gap in the middle. A 1-mm plunger tip was positioned on the materials. Pressure was applied at the center of the material in each hole with the Instron probe moving at a speed of $0.5 \mathrm{~mm} /$ min. The greatest force applied to the materials at the time of dislodgement was recorded in newtons. The push-out bond strength was calculated in megapascals according to the formula $N / 2 \pi r h$, where $N$ is the maximum force applied to the material at the time of dislodgement, $\pi$ is the constant 3.14, $r$ is the root canal radius, and $h$ is the thickness of the dentin slice.

After the measurements, the types of failures were examined under a stereomicroscope at 8X magnification (Olympus Corporation, Taichung, Taiwan). Bond failures were classified as adhesive, cohesive, or mixed.

\section{Statistical Analysis}

The normality of data distribution was examined using the Shapiro-Wilk test. As the data were normally distributed, parametric tests were used. The independent t-test was used for comparisons between the groups. The statistical analysis was performed using IBM SPSS Statistics version 24 (IBM, Armonk, NY, USA) for Windows. The level of statistical significance was set to $5 \%$. 


\section{Results}

Table 1 shows the mean push-out bond strength values obtained from the displacement of the materials in the TCA and non-TCA groups and the ProRoot MTA, Harvard MTA, and Biodentine subgroups. TCA had no statistically significant effect on the bonding strength of the tested materials $(P>.05)$. The Harvard MTA subgroup had the lowest mean bond strength values $(2.25$ $\pm 0.79 \mathrm{MPa}$ ), whereas the Biodentine subgroup had the highest $(10.49 \pm 3.32 \mathrm{MPa})$. Fig. 2 presents the results in a graph.

The most common bond failure types were mixed in the ProRoot MTA subgroup (60\%) and cohesive in the Harvard MTA (60\%) and Biodentine (70\%) subgroups (Table 2). Stereomicroscopic images of samples are shown in Fig. 3.

\section{Discussion}

TCA is manufactured by the chlorination of acetic acid, and its aqueous solution is highly acidic, yielding a $\mathrm{pH}$ of 1.0 . When applying TCA to a ECR area to exert its caustic effect, it may makes contact with dental hard tissues (22). Khoroushi and Tavasoli reported the contact of TCA with enamel have a positive effect on the shear bond strength of resin composite to enamel (23). Although the effects of TCA on resin composite have been investigated, to the best knowledge, no study has examined whether TCA has an effect on the push-out bond strength of MTA and Biodentine. TCA did reduce the push-out bond strength, especially of Biodentine. However, this decrease did not significantly affect the push-out bond strength of the tested materials. Therefore, our first null hypothesis was accepted. This result is not in line with previous studies reporting that acidic environments significantly affect the physical and chemical properties of MTA and Biodentine (21). This inconsistency may be due to the fact that in this study, TCA was applied for $1 \mathrm{~min}$ before the materials were placed in the holes, whereas previous studies exposed the tested materials to large amounts of acetic acid $(24,25)$, EDTA $(17,21)$, or citric acid (17) for more than $1 \mathrm{~min}$, thus significantly affecting their push-out bond strength.

Table 1. Mean and standard deviation of the push-out bond strength values (MPa) for the displacement of tested materials from the samples. (SD: Standart deviation; TCA: Trichloroacetic acid, $\mathrm{P}<.05$ )

\begin{tabular}{|c|c|c|}
\hline & Mean \pm SD & $P$. \\
\hline ProRoot MTA & $4.08 \pm 2.75^{b}$ & \\
\hline ProRoot MTA + TCA & $4.06 \pm 2.28^{b}$ & \\
\hline$P$. & 0.985 & \\
\hline Harvard MTA & $2.25 \pm 0.79^{a}$ & \\
\hline Harvard MTA + TCA & $2.32 \pm 0.82^{\mathrm{a}}$ & 0.042 \\
\hline$P$. & 0.863 & \\
\hline Biodentine & $10.49 \pm 3.32^{c}$ & \\
\hline Biodentine + TCA & $8.79 \pm 2.78^{c}$ & \\
\hline$P$. & 0.230 & \\
\hline
\end{tabular}

In our study, ProRoot MTA showed predominantly mixed failure, whereas Harvard MTA and Biodentine displayed mostly cohesive failure. A previous study found higher $\mathrm{Ca}^{+2}$ ion release with Harvard MTA than with ProRoot MTA after seven days and lower solubility of the former than the latter (26). Ion release results in a porous surface structure, which weakens the material's structure and reduces its cohesion (27). It is thus possible that Harvard MTA may have broken up by itself, resulting in cohesive rather than adhesive bond failure. The high calcium ion release observed in Biodentine is associated with a higher proportion of tricalcium silicate than in MTA (28) and may result in the presence of cohesive failure in Biodentine, as in Harvard MTA. Additionally, previous studies reported that MTA-dentin bond failures were usually adhesive $(10,16)$, but in our study, it may be possible to observe mixed or cohesive bond failures depending on the use of TCA.

In a previous study, roots filled with Biodentine displayed significantly greater push-out bond strength than Harvard and ProRoot MTA, while there was no statistically significant difference between the latter two (20). In our study, Biodentine

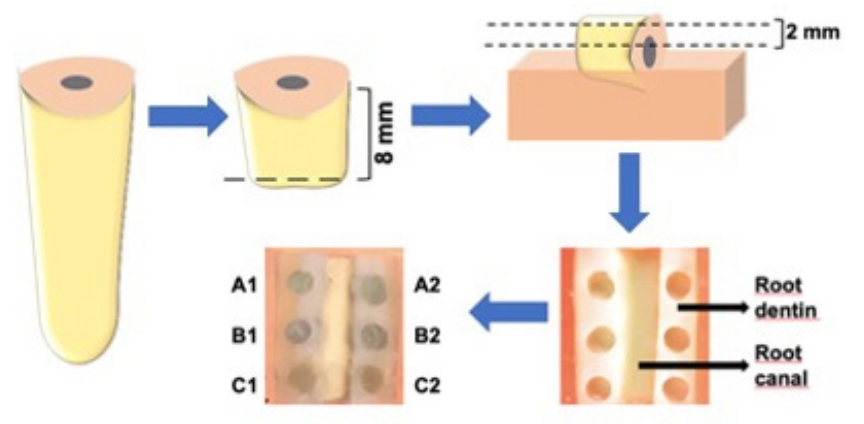

Figure 1. Preparation of the samples for the push-out test. (A1) ProRoot MTA. (A2) ProRoot MTA + TCA. (B1) Harvard MTA. (B2) Harvard MTA + TCA. (C1) Biodentine. (C2) Biodentine + TCA

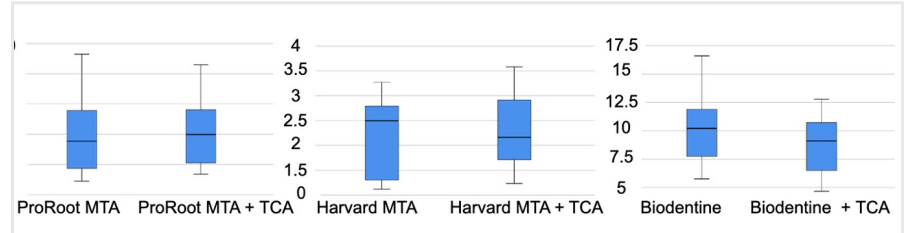

Figure 2. Box plot of the push-out bond strength (MPa) of the tested materials
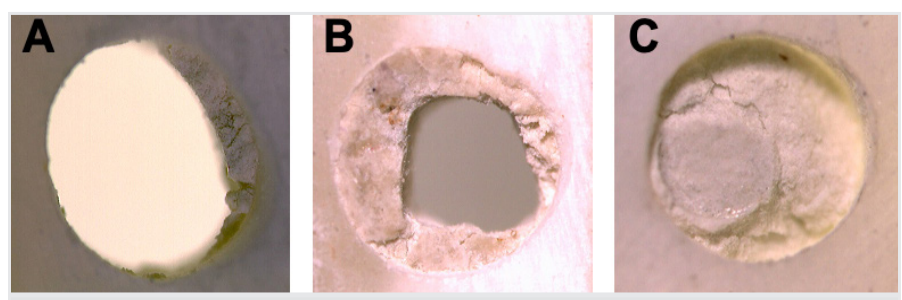

Figure 3. Representative failure types. (A) ProRoot MTA mixed failure. (B) Harvard MTA cohesive failure. (C) Biodentine cohesive failure 
also exhibited the greatest push-out bond strength, but there was also a statistically significant difference between ProRoot MTA and Harvard MTA, with the latter exhibiting significantly less push-out bond strength. According to these results, our second null hypothesis was rejected.

Harvard MTA is composed of $75 \mathrm{wt} \%$ calcium magnesium orthosilicate (merwinite), while ProRoot MTA contains 90\% tricalcium silicon pentaoxide (hatrurite) (26). Merwinite exhibits low solubility and good mechanical properties (29). On the other hand, the fact that Harvard MTA contains a high proportion of merwinite, unlike ProRoot MTA, may be responsible for the lower push-out bond strength of Harvard MTA. A previous study found that Biodentine and ProRoot MTA had comparable bond strength in apical dentin, but Biodentine exhibited significantly greater bond strength in coronal dentin (15). In our study, it may be possible to find this result depending on the use of the coronal part of the root. Biodentine is made of smaller particles than other cements, which allows deeper penetration into dentine tubules (30). This ability, combined with its short setting time and the presence of calcium chloride, might explain Biodentine's relatively greater push-out bond strength.

\section{Study Limitations}

The limitation of this study is that TCA-induced changes in the dentin walls were not scanned with a microscope such as the scanning electron microscope, which provides more detailed examination. In further studies, it will be more appropriate to examine TCA-induced changes in the dentin walls in more detail.

\section{Conclusion}

The results of this study indicate that the bond strength of Biodentine is greater than that of ProRoot and Harvard MTA and that Harvard MTA exhibits the least bond strength. TCA does not significantly affect the push-out bond strength of MTA or Biodentine.

\section{References}

1. Patel S, Kanagasingam S, Pitt Ford T. External cervical resorption: a review. J Endod 2009;35:616-25.

2. Andreasen JO. External root resorption: its implication in dental traumatology, paedodontics, periodontics, orthodontics and endodontics. Int Endod J 1985;18:109-18.

3. Bansal P, Nikhil V, Kapur S. Multiple idiopathic external apical root resorption: a rare case report. J Conserv Dent 2015;18:70.

4. Heithersay GS. Treatment of invasive cervical resorption: an analysis of results using topical application of trichloracetic acid, curettage, and restoration. Quintessence Int 1999;30:96-110.

5. Baroudi K, Samir S. Sealing Ability of MTA Used in Perforation Repair of Permanent Teeth; Literature Review. Open Dent J 2016;10:278-286.

6. Koh ET, McDonald F, Pitt Ford TR, Torabinejad M. Cellular response to Mineral Trioxide Aggregate. J Endod. 1998;24:543-547.
7. Tanalp J, Karapinar-Kazandag M, Ersev H, Bayırlı G. The status of mineral trioxide aggregate in endodontics education in dental schools in Turkey. J Dent Educ 2012;76:752- 8.

8. Laurent P, Camps J, De Meo M, Dejou J, About I. Induction of specific cell responces to a $\mathrm{Ca}(3) \mathrm{Sio}(5)$-based posterior restorative material. Dent Mater 2008;24:1484-94.

9. Laurent P, Camps J, About I. Biodentine TM induces TGF-B1 release from human pulp cells and early dental pulp mineralization. Int Endod J 2012;45:439-48.

10. Guneser MB, Akbulut MB, Eldeniz AU. Effect of various endodontic irrigants on the push-out Bond strength of Biodentine and conventional root perforation repair materials. J Endod 2013;39:380384.

11. Nagahara T, Takeda K, Aida Y, Iwata T, Yagi R, Kurihara H. Combined endodontic and periodontal management of a class 3 invasive cervical resorption in a mandibular first molar. Clin Case Rep 2018;6:2005-2010.

12. Heithersay GS. Invasive cervical resorption. Endod Topics 2004;7:73-92.

13. Heithersay G. Management of tooth resorption. Aust Dent J 2007;52:105-121.

14. Schwartz RS, Robbins JW, Rindler E. Management of invasive cervical resorption: observations from three private practices and a report of three cases. J Endod 2010;36:1721-30.

15. Majeed A, Alshwaimi E. Push-Out Bond Strength and Surface Microhardness of Calcium Silicate-Based Biomaterials: An in vitro Study. Med Princ Pract 2017;26:139-145.

16. Saghiri MA, Shokouhinejad N, Lotfi M, Aminsobhani M, Saghiri AL. Push-out bond strength of mineral trioxide aggregate in the presence of alkaline pH. J Endod 2010;36:1856-1859.

17. Buldur B, Öznurhan F, Kaptan A. The effect of different chelating agents on the push-out bond strength of proroot mta and endosequence root repair material. Eur Oral Res 2019;53:88-93.

18. Orhan EO, Irmak Ö, Mumcu E. Evaluation of the bond strengths of two novel bioceramic cement using a modified thin-slice push-out test model. Int J Appl Ceram Technol 2019;16:1998- 2005.

19. Shokouhinejad N, Nekoofar MH, Iravani A, Kharrazifard JM, Dummer PMH. Effect of acidic environment on the push-out bond strength of mineral trioxide aggregate. J Endod 2010;36:871-874.

20. El-Maaita AM, Qualtrough AJE, Watts DC. The effect of smear layer on the push-out bond strength of root canal calcium silicate cements. Dent Mater 2013;29:797-803.

21. Jain P, Nanda Z, Deore R, Amit G. Effect of acidic environment and intracanal medicament on push-out bond strength of biodentine and mineral trioxide aggregate plus: an in vitro study. Med Pharm Rep 2019;92:277-281.

22. Lewinstein I, Rotstein I. Effect of trichloracetic acid on the microhardness and surface morphology of human dentin and enamel. Endod Dent Traumatol. 1992;8(1):16-20.

23. Khoroushi M, Tavasoli M. The Effect of Trichloracetic Acid as a Hemostatic and Etching Agent on the Morphological Characteristics 
and Shear Bond Strength of Resin Composite to Enamel. Oper Dent 2010;35:187-193.

24. Thomas B, Chandak M, Deosarkar B. Comparison of Acidic versus Alkaline Environment for Furcation Perforation Repair among Calcium Silicate Based Materials: An in vitro Comparative Study. JAMMR 2017;19:1-8.

25. Hashem AA, Wanees Amin SA. The effect of acidity on dislodgment resistance of mineral trioxide aggregate and bioaggregate in furcation perforations: an in vitro comparative study. J Endod 2012;38:245-9.

26. Galal M, Zaki DY, Rabie MI, El-Shereif SM, Hamdy TM. Solubility, $\mathrm{pH}$ change, and calcium ion release of low solubility endodontic mineral trioxide aggregate. Bull Natl Res Cent 2020;44:42.
27. Stefaneli Marques JH, Silva-Sousa YTC, Rached-Júnior FJA, Macedo LMD, Mazzi-Chaves JF, Camilleri J, et al. Push-out bond strength of different tricalcium silicate-based filling materials to root dentin. Braz Oral Res 2018;32:18.

28. Camilleri J, Sorrentino F, Damidot D. Investigation of the hydration and bioactivity of radiopacified tricalcium silicate cement, Biodentine and MTA Angelus. Dent Mater 2013;29:580-93.

29. Hafezi M, Abbasi-Shahni M, Zamanian A, Heseraki S. Preparation and characterization of whitlockite-merwinite nanocomposite. J Ceram Process Res 2013;14:96-99

30. Atmeh AR, Chong EZ, Richard G, Festy F, Watson TF. Dentincement interfacial interaction: calcium silicates and polyalkenoates. J Dent Res 2012;91:454-9. 